
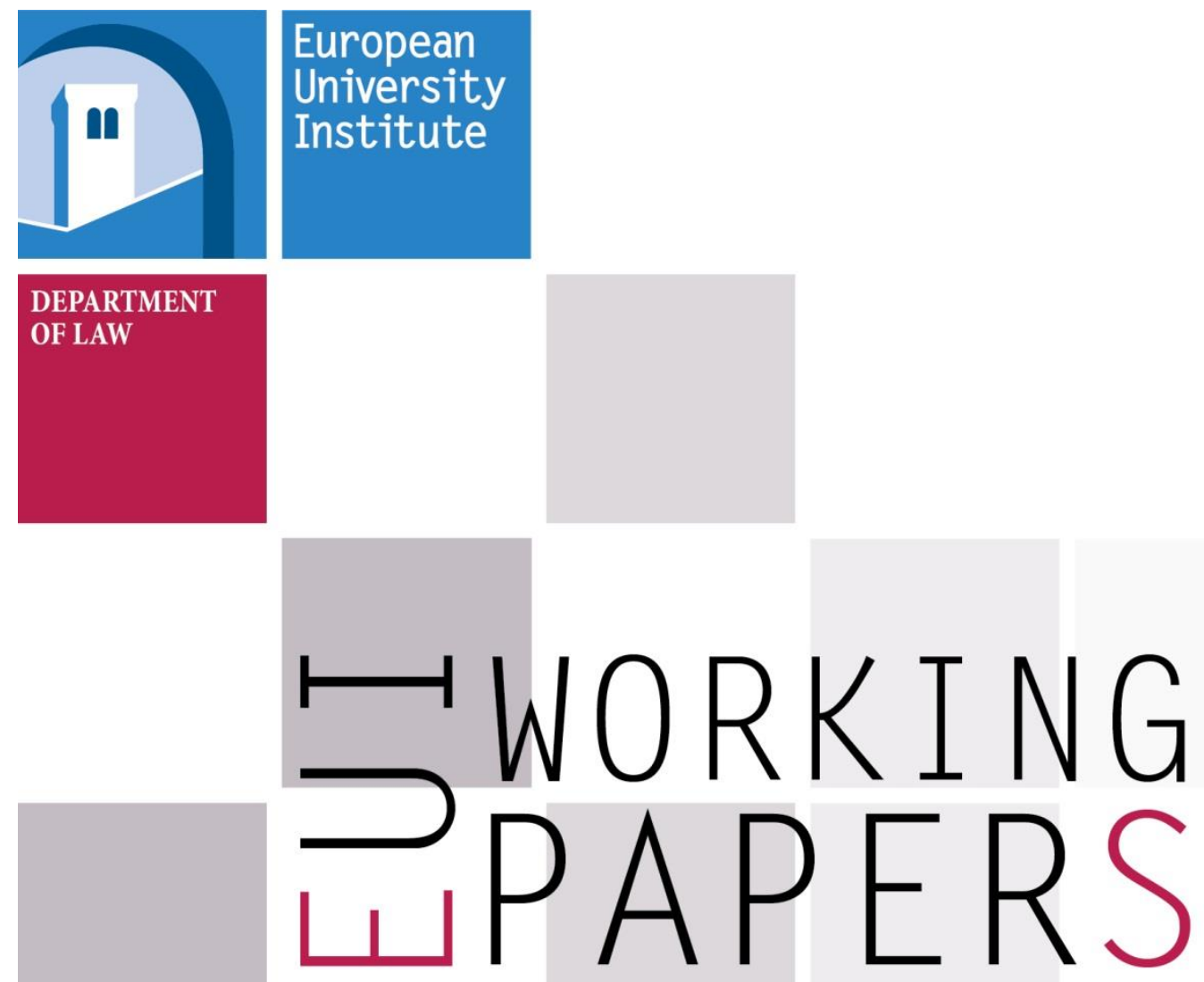

LAW 2021/02

Department of Law

\title{
TRIPS Through A Military Looking Glass
}

Peter Drahos 

European University Institute Department of Law

\section{Trips Through A MILITARy LOOKING Glass}

Peter Drahos

EUI Working Paper LAW 2021/02 
This text may be downloaded for personal research purposes only. Any additional reproduction for other purposes, whether in hard copy or electronically, requires the consent of the author, editor. If cited or quoted, reference should be made to the full name of the author, editor, the title, the working paper or other series, the year, and the publisher.

ISSN 1725-6739

(C) Peter Drahos, 2021

Printed in Italy

European University Institute

Badia Fiesolana

I-50014 San Domenico di Fiesole (FI)

Italy

www.eui.eu

cadmus.eui.eu 


\begin{abstract}
The paper draws on an argument from Hanns Ullrich that the Agreement on the Trade-Related Aspects of Intellectual Property Rights (TRIPS) suffers for a legitimacy gap. This gap takes the form of an external conditioning of states' sovereignty over innovation in markets. The paper argues there is a less-discussed and somewhat darker legitimacy gap of TRIPS. This gap relates to the US national security state (NSS) and its use of intellectual property to regulate globally innovation in weapons systems. The paper traces the links between the NSS, intellectual property and weapons innovation from World War II to the present day. TRIPS has lost legitimacy in the eyes of the NSS because it has failed to hold back China's innovation in defense-sensitive areas such as 5G technology. Drawing on the work of Carl Schmitt, the paper offers a phenomenological reading of the NSS' view of legitimacy. The paper finishes with an examination of the implications of Schmitt's friend-enemy distinction for the future of intellectual property and the US-China relationship.
\end{abstract}

\title{
Keywords
}

Carl Schmitt, China, intellectual property, legitimacy, military innovation, national security state, TRIPS 
Author contact details:

Peter Drahos

Law Department

European University Institute

Peter.drahos@eui.eu 


\section{Table of contents}

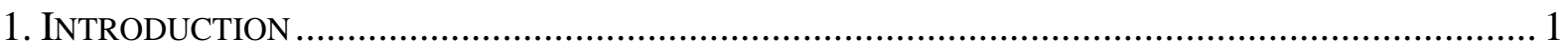

2. The Origins of the US National Security State And Military InNovation .............. 3

3. THE NSS AND US MULTINATIONALS: THE GLOBAL PARTNERSHIP YEARS ............................... 6

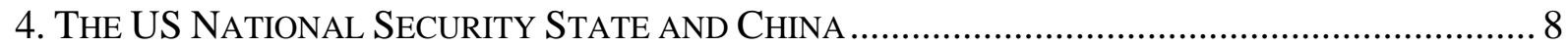

5. LEGITIMACY IN THE EYES OF THE NATIONAL SECURITY STATE …................................... 12

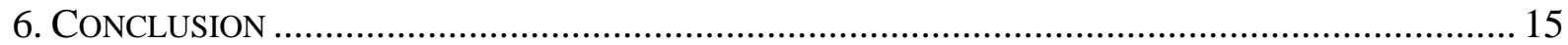





\section{Introduction}

\subsection{The political legitimacy gap of TRIPS}

On December 151993 Peter Sutherland, the Director General of the General Agreement on Tariffs and Trade tapped a wooden hammer on the table and pronounced "I gavel the Uruguay Round as concluded". 1 The Uruguay Round had begun in Punta Del Este seven years earlier, in September of 1986. Among the final set of agreements presented to participating states for signing at Marrakesh on April 151994 was the Agreement on the Trade-Related Aspects of Intellectual Property Rights (TRIPS). The US had made it clear that an agreement on intellectual property was central to its negotiating agenda. No IP, No Round had been its consistent message.

In a chapter published in 2016, Hanns Ullrich revisits the political foundations of TRIPS. TRIPS, in his words, 'left a legitimacy gap underneath the legal obligations entered into by the parties'. 2 Shortly stated, this legitimacy gap comes about because of a reduction of state sovereignty over the setting of property rights for innovation. The legitimacy gap runs deep in two ways. First, in order to gain access to international trade states must 'accept a system of property rights whose objectives and operation, boundaries and effects are determined externally and by foreign interests'. 3

Second, and even more worryingly, the dynamics of comparative advantage are compromised when state sovereignty over market regulation is eroded. In essence, states have what can be thought of as an architectural trusteeship over the organization of markets. On a social contract view of the state, the state ought to regulate property rights in ways that are consistent with its comparative advantage. So, to take a simple example but one which makes the point salient, if the farmers of a state have a comparative advantage in the production of bananas, the state has an obligation to provide those public goods needed for banana production that the free market cannot provide.

Matters become much more complicated when we begin to think of examples in which comparative advantage moves away from its classical Ricardian roots in natural factors of production and into a global market economy in which national advantages of production depend much more on concentrations of human capital and the use of knowledge. Comparative advantage becomes much more mobile. Advantages in banana growing may be gained through genetic engineering. States, on a social contract view of their duties, still continue to have an obligation to regulate property rights in ways that are consistent with comparative advantage. But their capacity to move to or create new forms of comparative advantage based on investment in human capital and knowledge networks faces in TRIPS, as Ullrich puts it, 'a systemic conditioning of Members' domestic markets for international trade'. ${ }^{4}$ This systemic conditioning is not one of states' choosing, but rather the outcome of the efforts of a small but politically powerful network that was responsible for TRIPS. ${ }^{5}$

\footnotetext{
${ }^{1}$ Roger Cohen, 'The World Trade Agreement: The Overview; GATT Talks End in Joy and Relief' New York Times (New York, 16 December 1993) Section D, 1.

${ }^{2}$ Hanns Ullrich, 'The Political Foundations of TRIPS Revisited' in Hanns Ullrich, Reto M. Hilty, Matthias Lamping, Josef Drexl (eds), TRIPS plus 20: From Trade Rules to Market Principles (Springer, 2016) 98

${ }^{3}$ Hanns Ullrich, 'The Political Foundations of TRIPS Revisited' in Hanns Ullrich, Reto M. Hilty, Matthias Lamping, Josef Drexl (eds), TRIPS plus 20: From Trade Rules to Market Principles (Springer, 2016) 98

${ }^{4}$ Hanns Ullrich, 'The Political Foundations of TRIPS Revisited' in Hanns Ullrich, Reto M. Hilty, Matthias Lamping, Josef Drexl (eds), TRIPS plus 20: From Trade Rules to Market Principles (Springer, 2016) 99

5 See, for example, Peter Drahos, 'Global Property Rights in Information: The Story of TRIPS at the GATT' (1995) 13 Prometheus 6; Susan.K. Sell, 'Intellectual property protection and antitrust in the developing world: crisis, coercion, and choice' (1995) 49 International Organization 315; Michael Ryan, Knowledge Diplomacy: Global Competition and the Politics of Intellectual Property (The Brookings Institution 1998); Peter Drahos with John Braithwaite, Information
} 
The legitimacy gap identified by Hanns Ullrich is a real one. As he shows, a large literature has been generated over the years exploring how the provisions of TRIPS might be interpreted or how it might be reformed to close the legitimacy gap. ${ }^{6}$ One can characterize these as 'rulish' approaches. The hope behind these approaches is that the TRIPS legitimacy gap will close because the new rules and interpretations properly arrived at fit with a conception of legitimacy based on the rule of law. As is well known, Max Weber suggested that the use of rationally created rules could legitimate the power of command by one over others.

In the remainder of this chapter I outline an argument for why the TRIPS legitimacy gap is not likely to be solved, no matter how much we invoke the rulish arts of lawyers, and why the gap is likely to widen. Like Hanns Ullrich, I propose to revisit the political foundations of TRIPS, but unlike him I have a more negative message to deliver about what those foundations hold for the regulation of innovation. As will be clear by the end of the paper, I hope that Hanns Ullrich is right and that I am wrong, since the implications of my view are certainly bleaker than those that stem from his.

\subsection{Bleak TRIPS}

TRIPS has a broader context to which not much attention has been paid. This neglected context relates to an institution that has been around for a long time and whose interest in innovation is probably matchless, namely the military.

In particular, my interest is the US national security state (NSS). Most of the focus on TRIPS has been from a normative, private law, trade law, or innovation perspective. Largely omitted from the analysis of TRIPS has been the systems, networks and functions that together provision state security. Embedding the evolution of TRIPS in the broader context of the NSS will help us to make more sense of at least some of the events that have followed TRIPS, events such as the Obama Administration's increased emphasis on trade secret protection, and Trump's trade war against China. As the TRIPS literature around the negotiation of TRIPS has shown, the US and US multinationals during the Uruguay Round invested hugely in the creation of an intellectual property agreement, as well as a dispute resolution procedure with genuine enforcement power. ${ }^{8}$ And yet in the years following TRIPS, the US shifted the action to bilateral agreements and the Obama Administration commenced crippling the WTO's dispute resolution process.

To fully understand this giant switch requires us to understand another TRIPS legitimacy gap, one that exists in the eyes of the US NSS. For the NSS, TRIPS has done little to slow the rise of China as a scientific and innovation power. Put starkly, for the US there is a sense in which TRIPS now lacks legitimacy.

One immediate objection to characterizing this as a legitimacy argument is to ask what kind of legitimacy is at stake here. TRIPS is an international agreement. It was concluded as a matter of de jure sovereignty by its signing states at Marrakesh in 1994. Its source of legitimacy lies in the notion of autonomous contracting and ultimately the rule of international law. Moreover, the whole point of the agreement is not to slow the rise of a country's scientific and innovation capability but rather to incentivize it. While economists can reasonably disagree as to how useful intellectual property rights are in stimulating innovation, there is no disagreement that this has to be justification for these rights.

Feudalism: Who Owns the Knowledge Economy? (Earthscan 2002); Duncan Matthews, Globalising Intellectual Property Rights: The TRIPs Agreement (Routledge 2002).

${ }^{6}$ See the discussion by Hanns Ullrich, 'The Political Foundations of TRIPS Revisited' in Hanns Ullrich, Reto M. Hilty, Matthias Lamping, Josef Drexl (eds), TRIPS plus 20: From Trade Rules to Market Principles (Springer, 2016) 103-107.

${ }^{7}$ Max Weber, 'Politics as a Vocation' in From Max Weber: Essays in Sociology (first published in 1919, H. H. Gerth and C. Wright Mills, eds and trs, OUP 1946) 77.

${ }^{8}$ See fn 5 above. 
Surely, the US cannot object to the legitimacy of an agreement that properly draws on the authority of international law. Nor can it ascribe to TRIPS a purpose that is avowedly inconsistent with the accepted public policy rationale for intellectual property rights, namely that they exist to incentivize innovation.

In the remainder of this chapter I will not be arguing that these objections are wrong, but rather they simply miss the point when it comes to understanding the world as it is. The US believes it has a legitimacy style argument for its position. I do not think that it is persuasive but, on a phenomenological reading of its experience, it holds to this legitimacy belief as a form of 'inner justification'. Understanding this phenomenology of legitimacy will give us a better explanation of past events and perhaps a better read on likely future events.

\section{The Origins of the US National Security State and Military Innovation}

\subsection{Origins}

The origins of the US national security state, argues Daniel Yergin, are to be found in the break-up of the grand alliance forged by Roosevelt, Stalin and Churchill in 1945 at Yalta. ${ }^{10}$ Two months after the Yalta meeting Roosevelt was dead. A little more than two months after his death, Churchill lost the general election to the Labour Party. US and the Soviet relations began to chill, quickly entering that dangerous long period known as the Cold War. As Yergin's documentary analysis shows the phrase 'national security', which had not been much in use before 1940, was by the late 1940s on the lips of many in US defence policy circles.

Much more important than the incantation of the phrase was the organizational outlook it engendered. It became a highly flexible framing concept capable of absorbing and re-framing almost any issue as one of 'national security'. Through the spectacles of national security existing threats were magnified and many new ones seen, in continents such as Africa, once thought too remote to pose threats by those who had seen virtue in US isolationism. A deep organizational response accompanied the national security mentality. The US began to take steps to put itself in a constant state of readiness for war. The national security state would be the militarily prepared state. It would also be the constantly militarily innovative state. It would become the 'innovation enterprise that concentrates national responsibility for science and technology'. ${ }^{11}$

\subsection{Organizing for Innovation in Weapons}

\subsubsection{The R\&D Money Pump}

One clear lesson from World War II was that the probability of victory would be heavily affected by discovery, invention and innovation in weaponry. The war had seen combatant states produce waves of innovation ranging from synthetic rubber, which the US needed once the Japanese captured key centres of natural rubber production in southeast Asia, to the most powerful weapon then ever produced, the atom bomb. States were, when it came to weaponry, locked into innovation races. Nazi Germany continued with the development of jet engines and fuels until its final days. ${ }^{12}$ Its development of the V-

\footnotetext{
${ }^{9}$ Weber's phrase. See Max Weber, 'Politics as a Vocation' in From Max Weber: Essays in Sociology (first published in 1919, H. H. Gerth and C. Wright Mills, eds and trs, OUP 1946) 77.

${ }^{10}$ Daniel Yergin, Shattered Peace: The Origins of the Cold War and the National Security State (Andre Deutsch, 1978).

${ }^{11}$ Linda Weiss, America Inc.?: Innovation and Enterprise in the National Security State (Cornell University Press, 2014)

12 Hermione Giffard, 'Engines of Desperation: Jet Engines, Production and New Weapons in the Third Reich' (2013) 48 Journal of Contemporary History 821.
} 
2 rocket showed that in the future there would no safety in distance from an adversary. The Manhattan Project was itself a demonstration of what was possible if a state brought together academic science, the corporate sector and government resources. It was not just the Manhattan project where this had been shown. Companies from the petro-chemical industry such as Dow Chemical and Du Pont had delivered new chemical weapons such as napalm. ${ }^{13}$ For defence planners there was a clear message: innovation in technology, both radical and incremental, was key to the security of the state. If the US was to stay ahead in weapons innovation races, its military, industrial and academic organizational structures would have to become much more integrated, much more networked.

It is easy to forget the scale and speed at which this military industrial re-organization took place in the US in the second half of the 1940s. Investing in R\&D was put front and centre of US security planning. Prior to World War II, the US military for the most part conducted its own R\&D through facilities such as the Naval Research Laboratory, navy shipyards or the system of manufacturing arsenals that served the weapons development needs of the US Army. ${ }^{14}$ After World War II this in-house approach was replaced by an out-sourcing approach to R\&D. This out-sourcing approach was of a distinctive kind. Civilian sector science and R\&D became absorbed into a network of innovation and production for US weapons system development.

One of the principal architects of this network approach to US military innovation was Vannevar Bush. As the wartime director of the Office of Scientific Research and Development, he had seen the benefits of distributing large sums of R\&D to civilian laboratories and scientists in the form of breakthrough innovations such as the atom bomb, the microwave radar and the radio proximity fuse. ${ }^{15}$ It was also clear that developing new aircraft, nuclear submarines and applying the latest in electronics to new weapons systems would require the intimate involvement of industry and universities. ${ }^{16}$ After World War II, the various arms of the US military, the army, the navy and the air force developed boards and committees to oversee R\&D spending. Research and development became one the central functions of the armed forces, a function which saw scientists from the private sector sitting on key advisory boards located in the highest levels of the security establishment, such as the White House and the Office of the Secretary of Defense, helping to plan weapons projects. ${ }^{17}$ Research and development contracts were rolled out to industry in an assembly-line fashion. These contracts were not just for applied research but also for more basic research of potential long-term interest to the armed services. Special offices like the Office of Naval Research and the Office of Air Research tracked and secured the research being carried out in the private sector. ${ }^{18}$ The aircraft manufacturing industry came in for special attention because long-range bombers to deliver nuclear weapons were seen as central to deterring the Soviet Union's expansionist ambitions. A combination of military R\&D funding of the industry and purchases of the industry's products by the military, which accounted for some $75 \%$ of its sales between 1948 and 1958 , eventually transformed the aircraft industry into the aerospace industry. ${ }^{19}$

13 Thomas L. Ilgen, ‘"Better Living Through Chemistry": The Chemical Industry in the World Economy' (1983) 37 International Organization 647, 653.

${ }^{14}$ Thomas C. Lassman, Sources of Weapons Systems Innovation in the Department of Defense: The Role of In-House Research and Development 1945-2000 (Center of Military History, United States Army 2008) 2.

15 Thomas C. Lassman, Sources of Weapons Systems Innovation in the Department of Defense: The Role of In-House Research and Development 1945-2000 (Center of Military History, United States Army 2008) 3.

${ }^{16}$ Thomas C. Lassman, Sources of Weapons Systems Innovation in the Department of Defense: The Role of In-House Research and Development 1945-2000 (Center of Military History, United States Army 2008) 2.

${ }^{17}$ Elliot V. Converse III, Rearming For The Cold War 1945-1960 (Historical Office, Office of the Secretary of Defence 2012) 12.

${ }^{18}$ Thomas C. Lassman, Sources of Weapons Systems Innovation in the Department of Defense: The Role of In-House Research and Development 1945-2000 (Center of Military History, United States Army 2008) 69.

${ }^{19}$ Elliot V. Converse III, Rearming For The Cold War 1945-1960 (Historical Office, Office of the Secretary of Defence 2012) 261. 
The US state, its military, and its corporations and universities began in the 1940s a long journey of networked interdependence, something that continues to this day. Eisenhower, towards the end of his presidency, may have come to hold reservations about the growth of what he famously called the 'military-industrial complex'. But he also recognized that the US should base its security, as he put it, 'upon military formations which make maximum use of science and technology in order to minimize numbers in men'. ${ }^{20}$

Every US president after Eisenhower has understood this basic precept. Science and technology provide the US with the innovation upon which rests the projection of its global military supremacy. Without innovation in military technology doctrines such as 'shock and awe' would have no credibility. An emperor may occasionally appear without new clothes without too great a consequence, but his army cannot risk appearing without new armour.

\subsubsection{Open Source Pragmatism and its Military Dictator}

During the first two or so decades of the organization of the US NSS, the US military managed intellectual property rights so as to meet innovation and production objectives. The private dominium of patents was, utterly unsurprisingly, not allowed to compromise a much more important goal, the security of US imperium. Patent right ownership over weapons technology was a matter of tough negotiation between the US military and the US firms being contracted to build weapon systems. The military was in the stronger position in these negotiating contests because private industry was in a situation of extreme dependence on the US military as its customer. Even if a private contractor was allowed to keep some patent rights, the military always made sure it had the right to shift the production of a weapons system that had been designed by one firm to another. ${ }^{21}$ Shifting production amongst industry players also meant transferring the technical knowhow needed to produce at the speed and level of quality demanded by the military. Essentially, the US military was managing the intellectual property of a very large industrial network. For example, by the mid-1950s there were more than 50,000 firms involved in contracting and sub-contracting arrangements for the development of weapons systems for the Air Force. ${ }^{22}$ The US military managed these large networks with a view to diffusing technical knowledge among the members of the network, thereby raising the baseline of innovation capability of all the member firms. This also allowed for the quick scaling in production of a contracted weapons system. In effect, the insiders in the defence procurement game had to play by open source style rules when it came to technical knowledge sharing, with a military dictator, as it were, enforcing this open source approach.

The networks of weapons innovation upon which the military relied were far too important to allow a single player to hold up those networks using patents and knowhow. Similarly, the military did not want a firm to improve its negotiating leverage through a control of key patents and knowhow. So, for example, even though Boeing started off as the main contractor for the delivery of the B-47 bomber, the Air Force in 1950, facing the start of the Korean War, issued contracts to Lockheed and Douglas for the building of B-47 bombers. ${ }^{23}$ Boeing was required to provide Lockheed and Douglas with technical assistance, the only issue up for debate being how much compensation Boeing would be given for sharing its technical knowledge.

\footnotetext{
${ }^{20}$ Elliot V. Converse III, Rearming For The Cold War 1945-1960 (Historical Office, Office of the Secretary of Defence 2012) 8.

${ }^{21}$ Elliot V. Converse III, Rearming For The Cold War 1945-1960 (Historical Office, Office of the Secretary of Defence 2012) 264.

${ }^{22}$ Elliot V. Converse III, Rearming For The Cold War 1945-1960 (Historical Office, Office of the Secretary of Defence 2012) 265.

${ }^{23}$ Elliot V. Converse III, Rearming For The Cold War 1945-1960 (Historical Office, Office of the Secretary of Defence 2012) 283.
} 
US patent applications on atomic technology had not been allowed to interfere in the work of the scientists involved in the Manhattan Project, with any such applications being suspended by means of secrecy orders. ${ }^{24}$ In the early decades of the Cold War there was simply too much at stake for anything other than an instrumentalist and pragmatic approach to the intellectual property of firms that were part of the US defence acquisition process. Sputnik 1, with its diameter of less than 60 centimetres, may have been a small satellite, but its successful launch by the Soviet Union in October of 1957 sent massive shockwaves through US defence establishment circles. The arms race, it was clear to all, was a genuine contest. The US redoubled its organizational efforts around space technology innovation because of its implications for ballistic missile defence. In 1958 the Advanced Research Projects Agency and the National Aeronautics and Space Agency were formed. ${ }^{25}$

\section{The NSS and US multinationals: the global partnership years}

Over the decades the US firms and industries servicing the Army, Navy and Air Force went through phases of restructuring and consolidation. As one would expect many firms over the decades came and went, but others benefited hugely from participating in the world's largest defence procurement market. In the 1940s and 50s firms such as Boeing, General Electric, Honeywell, IBM, Lockheed and Westinghouse were, along with thousands of other firms, part of networks competing in the US defence procurement market. These and other firms grew in size, turning themselves into genuine multinationals that, aside from helping the military to develop new technologies, captured export markets and forged global supply chains, many of which would end up being tied together in assembly lines in Chinese factories. ${ }^{26}$ US defence procurement has remained a vital market for these firms. In the US financial year 1990, for example, all of the firms mentioned above were in the top 20 of defence contractors, and in the year 2000 Boeing, General Electric, Honeywell and Lockheed remained in the top 20. ${ }^{27}$

By the 1970s export markets had also grown for many of the technologies produced for the US defence procurement market. US military industrial networks in the pursuit of weapons dominance posted a remarkable track record of innovation. Robert MacNeil, for example, puts on a short list of US military innovation achievements 'the Internet, the modern computer, cellular telephones, global positioning systems, semiconductors, jet engines, radar, sonar, satellites, weather forecasting technology, lithium ion batteries, nuclear technology, a range of synthetic materials, artificial intelligence, and the foundational development of the modern robotics, chemical and aviation industries' ${ }^{28}$ As I noted earlier, the US military did commit to funding long-term research by industry and the university sector after World War II. Many of these technologies, such as the computer, were dual use, with huge commercial value in the US domestic market as well as export markets.

The case of computers, which are of foundational importance to weapons systems, provides an illustration of the incentives for US multinationals and the US state to become partners in a global reshaping of the rules of intellectual property. In the first three decades after World War II, IBM dominated the mainframe computer industry, probably like no other firm ever has. It consolidated that dominance in the 1960s with the introduction of its System 360 family of computers designed to give users much more flexibility and compatibility. But the 1960s and 1970s also saw increasing attempts

\footnotetext{
${ }^{24}$ For the history see Alex Wellerstein, 'Inside the atomic patent office' (2008) 64 Bulletin of the Atomic Scientist 27.

${ }^{25}$ Thomas C. Lassman, Sources of Weapons Systems Innovation in the Department of Defense: The Role of In-House Research and Development 1945-2000 (Center of Military History, United States Army 2008) 93.

${ }^{26}$ On global supply chains and China see Richard Baldwin, The Great Convergence: Information Technology and the New Globalization (Belknap Press of Harvard University Press 2016).

${ }^{27}$ Rodrigo Carril and Mark Duggan, 'The Impact of Industry Consolidation on Government Procurement: Evidence from Department of Defense Contracting' (October 2018) NBER Working Paper No. 25160 34-35.

${ }^{28}$ Robert MacNeil, 'Between innovation and industrial policy: how Washington succeeds and fails at renewable energy' (2016) 34 Prometheus 173, 183.
} 
to assail what appeared to be IBM's unassailable market position. In Europe, states began to back national champions (for example, Germany with Siemens; France with Compagnie internationale pour l'informatique; the UK with International Computers Limited), to develop public programs of support (for example, the French Plan Calculs (1967-71, 1971-1975) and the German First and Second Data Processing Programs (1967-69 and 1969-70) and to use defence procurement to support national champions. ${ }^{29}$ Japan launched its 'Super High-Performance Computer Project'. Among other things, it was able to gain the use of IBM's patents as condition of access to its market. ${ }^{30}$ And it was not only IBM that was seeing competition and threats to its intellectual property in export markets. Large US pharmaceutical companies like Pfizer saw in Indian generic companies an emerging rival force.

By the time of the Uruguay Round, most US multinationals operating in high technology sectors could agree on the need for stronger protection and enforcement of US intellectual property, especially for strategic technologies such as software and semiconductors. Faced by this consensus position, the US state pushed for the best possible agreement on intellectual property.

It is important to stress that from TRIPS onwards the protection of US intellectual property in export markets becomes more and more of a priority for the US NSS. Protecting the intellectual property of US multinationals in export markets aids the ultimate goal of staying ahead in weapons systems innovation in at least two ways. First, through an expansion and strengthening of intellectual property rights in export markets, US multinationals increase the opportunity to extract economic rents from the sale of their technology, thereby increasing their ability to outspend competitors in R\&D races. This helps to ensure that the US R\&D base for military innovation remains dynamic. Second, intellectual property rights are a barrier to entry in innovation markets, one that requires high levels of legal capability to overcome. Through a globalization of intellectual property rules the US state and US firms were setting many more legal tripwires for innovators in other countries.

By staying ahead in weapons development, the US also creates incentives for individual countries that are in the market for the 'best' military technology to purchase from US companies. Over time purchasers of US weapons find themselves part of an intricate web of intellectual property licensing agreements from which extrication is very costly. And, of course, US multinationals working in defence procurement also work on their brand image. 'Nobody gets fired for buying IBM' is a phrase that used to be widely heard in technology circles.

If one has been ahead in military innovation races, as the US national security state has been for many decades, then the judgement about where one stands on intellectual property is relatively straightforward. There is everything to gain from insisting on stronger and stronger monopoly protection of one's military innovation. Intellectual property has not been the only means to protect US military technology. After World War II and with the help of the UK and France, the US established in 1949 the Coordinating Committee for Multilateral Export Controls (CoCom) for the purpose of blocking the export of strategically important military and dual-use industrial technologies to communist countries. ${ }^{31}$ The disintegration of the Soviet bloc saw the termination of CoCom in 1993. This was followed by the establishment of another informal regime in the form of the Wassenaar Arrangement for Export Controls for Conventional Arms and Dual Use Goods and Technologies in 1996. ${ }^{32}$

\footnotetext{
29 Timothy F. Bresnahan and Franco Malerba, 'Industrial Dynamics and the Evolution of Firms' and Nations' Competitive Capabilities in the World Computer Industry' in David C. Mowery and Richard R. Nelson (eds), Sources of Industrial Leadership: Studies of Seven Industries (Cambridge University Press 1999) 79, 101.

${ }^{30}$ Timothy F. Bresnahan and Franco Malerba, 'Industrial Dynamics and the Evolution of Firms' and Nations' Competitive Capabilities in the World Computer Industry' in David C. Mowery and Richard R. Nelson (eds), Sources of Industrial Leadership: Studies of Seven Industries (Cambridge University Press 1999) 79, 103.

${ }^{31}$ For the history see Stuart Macdonald, Technology and the Tyranny of Export Controls: Whisper Who Dares (Macmillan 1990).

${ }^{32}$ See https://www.wassenaar.org/about-us/.
} 
The US has also negotiated bilateral arrangements to protect defence sensitive industries. During the 1980s, the Japanese semiconductor chip industry was making serious inroads into the US domestic market with the Japanese equipment industry raising its share of the US market from 18 to 39 per cent. ${ }^{33}$ The US, backed by its semiconductor chip industry, responded by using its trade law to issue trade threats. In their shadow, it negotiated with Japan the 1986 Semiconductor Trade Agreement. ${ }^{34}$ Tariffs were imposed on Japanese goods in 1987 because in the eyes of the US, Japan had failed to respect the agreement.

In the same year, the US Defence Department formed a research consortium with US semiconductor companies. Examples abound of how US state capitalism moves into an activist governance of technology breakthroughs through its procurement power. They include the Very High Speed Integrated Circuit and the Very Large Scale Integrated Circuit programs of the 1970s and the Small Business Innovation Research program which over a 30 year period from 1982 saw a variety of US defence agencies invest more than $\$ 30$ billion in procurement activities. ${ }^{35}$

Intellectual property has always been a part of the management strategies of the US national security state. What has changed over time are the strategies themselves in response to new geo-political contexts and transformations in technology innovation. I would argue that the protection of intellectual property has become more important to US national security. The use of preferential trade agreements by the US to ratchet up standards of intellectual property protection, a management strategy that has been in full swing now for over two decades, suggests a strong belief in the strategic importance of intellectual property. ${ }^{36}$ US administrations have in recent times been making the connection between national security and intellectual property much more publicly explicit, especially in the context of the US-China relationship. We turn to this in the next section.

\section{The US National Security State and China}

Everywhere within the US security state alarm bells are being rung about China's capacities to acquire US technologies and what this means for US military power: ${ }^{37}$

China is playing the long game, finding our weak points, using any means possible — legal and illegal — to steal our data, plans, and technologies. Without action, what's in research and development now, what's stolen now... is what our service members will inevitably face on the battlefield.

Senior figures within the Trump Administration see in China's drive to innovate an existential threat to US technological dominance and security, as the following description of China's methods makes clear:

Unfortunately, it also involves industrial espionage and theft of technology and intellectual property, as well as forced technology transfers, predatory pricing, leveraging China's foreign direct investment, and strong-arm sales tactics in target markets, including the use of corruption.

\footnotetext{
${ }^{33}$ National Research Council, Maximizing U.S. Interests in Science and Technology Relations with Japan (National Academy Press 1997) 95.

${ }^{34}$ For a discussion of the effects of the agreement see Douglas A. Irwin, 'The U.S.-Japan Semiconductor Trade Conflict' in Anne O. Krueger (ed.), The Political Economy of Trade Protection (University of Chicago Press 1996) 5.

${ }^{35}$ For these and other cases see Linda Weiss, America Inc.?: Innovation and Enterprise in the National Security State (Cornell University Press, 2014).

${ }^{36}$ On the global ratchet for intellectual property protection see Peter Drahos, 'BITS and BIPS: Bilateralism in Intellectual Property' (2001) 4 Journal of World Intellectual Property 791.

${ }^{37}$ Kari Bingen, Deputy Under Secretary of Defense for Intelligence, quoted in (2020) 9(1), Access (Official Magazine of the Defense Counterintelligence and Agency) https://www.dcsa.mil/Portals/91/Documents/about/err/DCSA_ACCESS_v9i1_web1.pdf> accessed 20 May 2020.
} 
Make no mistake about it - China's current technological thrusts pose an unprecedented challenge to the United States. 38

Reports from US defence agencies over the years have steadfastly argued that the US can only stay ahead on the battlefield if it stays ahead in innovation. ${ }^{39}$ On this view China's theft of intellectual property is not an abstract freeriding problem or a positive externality gain in knowledge diffusion. Rather it is a national security problem because it allows China to acquire defence capability at lower cost.

In 2017, the Trump Administration commenced a section 301 investigation into China's intellectual property and technology transfer practices. ${ }^{40}$ This investigation ultimately culminated in the US imposing duties on Chinese goods, leading the US and China into a spiral of tit-for-tat tariff increases. The US launched the first tranche of tariff increases in June of 2018 and China immediately retaliated by increasing duties on goods of US origin. ${ }^{41}$ Over the next eighteen months the US and China took global markets through something of a roller coaster ride, as each increased tariffs, threatened further increases, acted on those threats, suspended tariffs for purpose of negotiating a deal and then went back into a fresh cycle of threats and tariffs as the talks broke down. In May of 2019 President Trump ordered the preparation of lists needed to impose a 25\% tariff on the remaining \$300 million worth of Chinese goods not yet subject to tariffs. However, the tariff increases also increased trade immiseration for both sides. In January of 2020 the US and China signed what is described in a USTR fact sheet as a 'Phase One' trade deal. ${ }^{42}$

One way in which to interpret this trade war, and probably the way in which the Trump Administration would like to see it interpreted, is to argue that it represents evidence of Trump's uniquely tough stance on trade and intellectual property. He has been prepared to do what other US administrations have not. This line of interpretation ignores how the successive US administrations have, over the decades, elevated the importance of intellectual property to innovation. Every US administration going right back to the Reagan Administration has through trade pressure and bilateral negotiations required China to do more and more on intellectual property. For example, if one looks at the history of Special 301 reviews carried out by the United States Trade Representative, China has been the principal enforcement priority. These reviews go back to the 1980s. ${ }^{43}$ After 2000, the link between intellectual property and national security was given more and more public prominence by US administrations. ${ }^{44}$

The real issue, I would argue, has not been China's failure to respect intellectual property but rather its capacity to adapt to the US-led globalization of intellectual property. In a remarkably

${ }^{38}$ Attorney General William P. Barr, 'Keynote Address at the Department of Justice's China Initiative Conference', February 6, 2020, https://www.justice.gov/opa/speech/attorney-general-william-p-barr-delivers-keynote-address-departmentjustices-china accessed 20 May 2020.

${ }^{39}$ Defense Security Service, Targeting U.S. Technologies: A Trend Analysis of Reporting From Defense Industry 2012 (Defense Security Service 2012) 67.

40 'Initiation of Section 301 Investigation; Hearing; and Request for Public Comments: China's Acts, Policies, and Practices Related to Technology Transfer, Intellectual Property, and Innovation', Federal Register 82, 163, 24 August 2017, 40213.

41 Congressional Research Service, Enforcing U.S. Trade Laws: Section 301 and China (June 26, 2019) https://fas.org/sgp/crs/row/IF10708.pdf accessed 20 May 2020.

42 Economic and Trade Agreement Between the United States of America and the People's Republic of China, January 15 2020, Fact Sheet, https://ustr.gov/sites/default/files/files/agreements/phase\%20one\%20agreement/US_China_Agreement_Fact_Sheet.pdf Accessed 20 May 2020.

${ }^{43}$ The reports can be accessed at <https://ustr.gov/issue-areas/intellectual-property/special-301/previous-special-301-reports>. Accessed 20 May 2020

44 Debora Halbert, 'Intellectual property theft and national security: Agendas and assumptions' (2016) 32 The Information Society 256. 
short space of time China built the world's largest patent office. ${ }^{45}$ Equally impressive has been the capacity of China's firms to use the international patent system. ZTE and Huawei became the top two applicants under the Patent Cooperation Treaty in 2016 in the field of digital technology. The World Intellectual Property Organization described this result as extraordinary given that both companies had only begun using the system about a decade ago. ${ }^{46}$ Patents are an imperfect proxy for innovation, but the capacity to assemble a patent portfolio of many thousands in which players like the US multinational Qualcomm are competing says something about the capabilities of these Chinese firms. The former Soviet Union may have launched Sputnik, but it never launched multinationals into global capitalist space.

Finally, and most worryingly for the US NSS, has been China's demonstrated capacity to achieve technological leadership in sectors of global infrastructural importance. The clearest case has been Huawei's development of 5G technology. China's lead in 5G technology has become something of a defining line in US thinking about China's technological progress and its implications for US security:

China has built up a lead in 5G, capturing 40 percent of the global 5G infrastructure market. For the first time in history, the United States is not leading the next technology era. ${ }^{47}$

For the US NSS, 5G forms part of a much larger technological contest in which it cannot afford to cede dominance to China if it is to stay ahead in the military innovation race. Recent reform proposals to the US export control system provide us with a glimpse of technological areas thought to matter to the weaponry of the twenty first century. Neurobiology, neurotech, neural networks, evolutionary and genetic computation, AI cloud technologies, microprocessor technology, advanced computing technology, and quantum information and sensing technology are all emerging or foundational technologies that are coming into focus for US export control. ${ }^{48}$

Here we arrive at the nub of the legitimacy gap that I signalled in my introduction. This gap lies in the failure of TRIPS as a dynamic instrument of national security protection. TRIPS like all creatures of law was a creature of context, albeit global context. At the time of the Uruguay Round, more and more US multinationals, many of which were also major players in US defence procurement, were exploiting their intellectual property in export markets. The US state was also releasing much more federally funded intellectual property onto the US market, allowing the private sector to own it. The thinking behind this transfer strategy was, to put it succinctly, 'let them own it and they will develop it'. Faster development meant faster access for the military to leading-edge technology. Beginning in 1980, laws such as the Stevenson-Wyndler Technology Innovation Act were passed allowing military laboratories like the Naval Research Laboratory to work with and transfer intellectual property to private firms or universities. $^{49}$

\footnotetext{
${ }^{45}$ Wenting Cheng and Peter Drahos, 'How China Built the World's Biggest Patent Office: The Pressure Driving Mechanism' (2018), 49 International Review of Intellectual Property and Competition Law 5.

${ }^{46}$ World Intellectual Property Organization, Patent Cooperation Treaty Review 2017 (WIPO 2017) 19.

${ }^{47}$ Attorney General William P. Barr, 'Keynote Address at the Department of Justice's China Initiative Conference', February 6, 2020, https://www.justice.gov/opa/speech/attorney-general-william-p-barr-delivers-keynote-address-departmentjustices-china accessed 20 May 2020.

${ }^{48}$ See the notice of the United States Bureau of Industry and Security, Department of Commerce, 'Review of controls for certain technologies', Federal Register, vol. 83 no. 223, November 19 2018, 58201. See also Export Control Reform Act 2018.

${ }^{49}$ For a discussion see Mark L. Montroll, 'The Transition Dilemma: Research and Development in the 1990s' in Shannon A. Brown (ed.), Providing the Means of War: Historical Perspectives on Defense Acquisition, 1945-2000 (United States Army Center of Military History and Industrial College of the Armed Forces 2005) 339.
} 
Protecting US intellectual property through pushing for the creation of a global trade-based platform in the form of TRIPS was, in the 1980s and 1990s, an important and necessary step to take. But in the words of an English saying, 'the best laid plans of mice and men often go awry'.

In the case of TRIPS things did, over time, go awry. The HIV-AIDS pandemic, which by the end of 1990s had killed almost 19 million people ${ }^{50}$, raised in public minds around the world deep questions of moral legitimacy about an agreement that was strengthening the monopoly position of US pharmaceutical multinationals on essential medicines. The genesis of TRIPS itself, with its links to global elites making law for the world, contributed to a growing public questioning of globalization. TRIPS, more than any other WTO agreement, provided evidence for the perils of globalization for citizen welfare. The wider anti-globalization critique took on a life in the streets as public demonstrations increasingly dogged WTO Ministerial meetings, the biggest and most violent of these being the 1999 'Battle in Seattle'. Nor did TRIPS deliver everything that the US national security state might have hoped for in terms of slowing China's drive to acquire technology. China adapted to TRIPS standards. If anything, TRIPS may have helped China, in the sense that its inclusion in the WTO made China prioritize learning the intellectual property game. China, after a long negotiation with the US on its accession to the WTO, entered the WTO trading system knowing that its capacity to survive as an exporter depended on it being able to work the rules of TRIPS.

Last, but by no means least, it became clear to the NSS that TRIPS standards were receding in relevance to the digital dynamism that was driving technology markets, including weapons technology. Developing countries, having conceded TRIPS standards to the US, were not prepared to see the TRIPS Council become a forum in which the US would make yet more gains on intellectual property. This essentially meant that TRIPS standards could not be adapted to changing technological contexts. TRIPS, after all, was negotiated in the 1980s well before key generational technological changes such as cloud computing, big data and machine learning. Among other things, trade secret protection, which has always been important, has become even more important in a world where the development and delivery of weapons depends on mathematical functions in codified rather than tacit form.

Trade secret protection is especially important to protecting the fine-tuning of the performance of an algorithm in relation to the function for which it is designed. Firms such as Google and Facebook routinely file patents for algorithms. But what is very important to note here is that mathematics is not just an outcome or product (for example, the demonstration of a proof) but also a process (for example, the process of arriving at proofs or more elegant proofs). Processes of algorithmic refinement are fundamental to improving the performance of software. In the case of highly used algorithms like Google's search algorithms these are refined on a daily or weekly basis in never-ending processes of optimization. For weapons systems development, drawing the curtains of secrecy over their governing equations and processes of adjustment is likely to be the most effective form of protection. While TRIPS does set a standard for trade secret protection in Article 39 this is a very open standard, allowing states to take diverse approaches to the formulation and enforcement of trade secret protection.

One can see in initiatives by the US much more emphasis being placed on extending the reach of trade secrecy. For example, the Obama Administration in a 2013 paper outlined a strategy for trade secret protection that included the targeting of trade secret protection in the Special 301 process and seeking new provisions on trade secrets in trade agreements, linking this strategy to national security concerns. ${ }^{51}$ According to US intelligence agencies, the use of cyber-techniques to steal digitally codified trade secrets had grown into a major threat, with China and Russia being the principal users of these techniques against the US. China and the US did, through a meeting between Xi Jinping and Barak

\footnotetext{
${ }^{50}$ UNAIDS, Report on the global HIV/AIDS epidemic (June 2000) < http://data.unaids.org/pub/report/2000/2000_gr_en.pdf> accessed 20 May 2020.

${ }^{51}$ Administration Strategy on Mitigating the Theft of U.S. Trade Secrets (February 2013) < https://www.justice.gov/criminalccips/file/938321/download> accessed 20 May 2020.
} 
Obama in September of 2015, come an agreement on cybersecurity. Both agreed neither country would 'conduct or knowingly support cyber-enabled theft of intellectual property'. ${ }^{52}$ A few years later a report based on input from the many agencies that make up the intelligence web of the US NSS concluded that while the volume of cyber traffic from China aimed at US trade secrets was less than before 2015, it was not low, with much of it directed against firms that were part of US defence procurement. ${ }^{53}$

TRIPS shows itself as old technology when one looks at the provisions on trade secrets in the draft text of the US, Mexico and Canada Agreement. These are not so much TRIPS plus as TRIPS quantum, such is the leap in detail and scope of trade secret protection. ${ }^{54}$ A section (Section I) consisting of eight articles is devoted to trade secret protection. Notable features of these standards include the express mention of the rights of trade secret holders against state-owned enterprises and the obligations of the parties to provide criminal penalties for trade secret misappropriation. ${ }^{55}$ The protection of secrecy is also to be found in the chapter on digital trade where a party cannot make access to a person's source code or algorithms owned by an outside person a condition of trade in that party's territory. ${ }^{56}$ This provision is aimed at countries such as China and Russia that demand source code reviews of foreign information technology products sold in their market. ${ }^{57}$

\section{Legitimacy in the eyes of the national security state}

\subsection{Carl Schmitt and some caveats}

In this final section of the paper I want to outline the other political legitimacy gap that exists in relation to TRIPS, the one that exists in the eyes of the US national security state. In order to do this I will draw on an analysis of the political developed by one of the twentieth century's most controversial lawyerphilosopher thinkers, Carl Schmitt.

One of the earliest facts one is confronted by in the many books and articles that engage with Schmitt's work is his membership of the Nazi Party from 1933. Schmitt has had many epithets heaped upon him, everything from the twentieth century's most sophisticated exponent of facism to 'one of the most brilliant critics of the Weberian world view'. ${ }^{58}$ The analysis of his theories now stretches across legal and political theory and more recently into international relations theory. ${ }^{59}$ As is common with controversial thinkers exegetical walls have been built around Schmitt's works. Obviously, my goal here is not to add more interpretive bricks to those walls. Rather, drawing on one of Schmitt's most well-known analytical claims that the essence of the political lies in the identification of friend and enemy, I offer an account of how legitimacy might be perceived by the NSS. My interest is in trying to

52 Fact Sheet: President Xi Jinping's State Visit to the United States, September 252015 , https://obamawhitehouse.archives.gov/the-press-office/2015/09/25/fact-sheet-president-xi-jinpings-state-visit-unitedstates accessed 20 May 2020.

53 National Counterintelligence and Security Center, Foreign Economic Espionage in Cyberspace (2018), https://www.dni.gov/files/NCSC/documents/news/20180724-economic-espionage-pub.pdf accessed 20 May 2020.

${ }^{54}$ The Agreement between the United States of America, the United Mexican States, and Canada will by means of a Protocol that has been signed by the three parties replace the North American Free Trade Agreement, coming into force on 1 July 2020.

${ }^{55}$ See Article 20.69 and Article 20.71.

${ }^{56}$ See Article 19.16.1.

57 National Counterintelligence and Security Center, Foreign Economic Espionage in Cyberspace, 2018, https://www.dni.gov/files/NCSC/documents/news/20180724-economic-espionage-pub.pdf, 13-14.

${ }^{58}$ See John P. McCormick, Carl Schmitt's Critique of Liberalism: Against Politics as Technology (Cambridge University Press 1997) 11-15, 314.

${ }^{59}$ On international relations see Louiza Odysseos and Fabio Petito (eds.), The International Political Thought of Carl Schmitt: Terror, liberal war and the crisis of global order (Routledge 2007). 
characterize the operational mindset or mentality of legitimacy in the NSS. Schmitt's friend-enemy distinction captures at a phenomenological level something of the inner life of legitimacy when the state transforms into a national security state in which military dominance and innovation become its overriding priority. I do not claim that this is a normatively defensible analysis of political legitimacy. My reason for exploring this Schmittean style account of political legitimacy is that it helps to explain why the US, after having invested so much in the creation of TRIPS and the WTO, seemingly has walked away from them. It also helps to explain why the US has so directly and aggressively engaged China on intellectual property.

\subsection{Schmitt's Concept of the Political}

In the essay Concept of the Political, Schmitt searches for what distinguishes the political from other systems. ${ }^{60}$ Like many early twentieth century Continental thinkers his method of identifying the antitheses and antinomies of systems remains in the shadow of Hegel's dialectical method. For Schmitt, the political draws its nature from the antithesis of friend and enemy. It is the political sphere or unit that makes ultimate judgements about association and unity versus disassociation and disunity. These decisions are constitutive of the 'all-embracing political unit, the state'. ${ }^{61}$ Schmitt insists on the autonomy of the antithesis. It cannot be derived from judgements of good or bad and is not to be confused with relations among economic competitors. The friend-enemy criterion is an empirical reality, an organizational truth about how political systems evolve identity. Schmitt does not argue that war is the aim of politics or that war is desirable but rather that it is an 'ever present possibility'. ${ }^{62}$ Dealing with this ever-present possibility is the task of the political system. While much of Schmitt's discussion of the friend-enemy grouping is couched in the abstract, sometimes obscure phrasing that often features in Continental philosophizing, it is reasonably clear that the sovereignty of state resides in those capable of taking the decisive step of war against an enemy. Being able to commit to war is evidence of the existence of a political unit that can be said to be sovereign.

Schmitt does not in the Concept of the Political spend time discussing legitimacy and says almost nothing about the military system. His target is a pure concept of the political. In other work, he does draw a distinction between legality and legitimacy, questioning one of the Weberian pillars upon which legitimacy is said to rest, rational law. ${ }^{63} \mathrm{I}$ am not interested here in following the implications of Schmitt's analysis for this Weberian form of legitimacy. Instead I want to focus on the question of how a national security state animated by Schmitt's friend-enemy grouping might come to perceive the political legitimacy of multilateral institutions.

\subsection{The friend-enemy distinction and the NSS}

We begin with two preliminary points. The first is that from its beginnings in the 1940s the NSS, as Daniel Yergin's history shows, has always operated with a strong sense of the friend-enemy grouping. The second point relates to the military system. Schmitt pays it little attention, giving it an instrumental status. But if we look to the history of the NSS what we see are flows of personnel from the military into the political and industrial systems. Famous generals like, for example, Colin Powell may decide not to enter politics, but these individual cases should not blind us to the systems integration of the

\footnotetext{
${ }^{60}$ Carl Schmitt, The Concept of the Political (First published 1932, Georg. Schwab tr, Expanded Edition, University of Chicago Press 2007).

${ }^{61}$ Carl Schmitt, The Concept of the Political (First published 1932, Georg. Schwab tr, Expanded Edition, University of Chicago Press 2007) 32.

${ }^{62}$ Carl Schmitt, The Concept of the Political (First published 1932, Georg. Schwab tr, Expanded Edition, University of Chicago Press 2007) 34.

${ }^{63}$ See in particular Carl Schmitt, Legality and Legitimacy (First published 1932, Jeffrey Seitzer, tr and ed, Duke University Press 2004).
} 
military, political and industrial networks making up the NSS. For example, the movement of retired officers from the military to large defence contractors like Boeing had by 1959 become a steady flow with some 750 former officers on the payroll of private contractors. ${ }^{64}$ By the 1980 s, the flows could be measured in thousands of officers. In this way the friend-enemy mentality of the political widened, establishing itself as a seemingly natural category of analysis and experience for those in NSS networks.

For the NSS it is axiomatic that security depends on the US market in weapons innovation remaining the most dynamic in the world. Intellectual property rights have become a hugely important tool to this end. They offer the US state strategies for intervening in and regulating what are often global innovation networks for technologies of potential military application. Property, that most fundamental institution of the state, through its application to knowledge and technology becomes inextricably fused with the political. Decisions about property can no longer be confined to the antinomies within economics or morals. On Schmitt's account the political legitimacy of the various international intellectual property agreements cannot be derived from the legality of those arrangements. Legality cannot be the core of legitimacy because this would be to threaten the political unit that bears decisive responsibility for drawing and acting upon the friend-enemy distinction. Upon new knowledge rests new, perhaps revolutionary materiel capability and upon materiel capability rests the capacity of the political to act on judgements of who is a 'real' or 'absolute' enemy. ${ }^{65}$ The legitimacy of property in a world in which property is a principal tool of regulation for rapid weapons innovation can only be derived from the political.

The state, argues Schmitt, should strive to establish the normal situation, this being one of peace. In the normal situation there are valid legal norms and so by implication judgements of legitimate authority can be made. But the political is also the ultimate arbiter of the 'right to demand from its own members the readiness to die and unhesitatingly to kill enemies' ${ }^{66}$ Ultimately legitimacy is not something to be derived from legal norms. To the extent one can speak of legitimacy on the existential plane of the extreme case (war), it is clear that the political decides. The political polices the application of the friend-enemy distinction. An international legal order cannot constrain the capacity of people to act on the basis of the friend-enemy distinction. The inability of a people to make or act upon this distinction means for Schmitt that it has no political existence. ${ }^{67}$

If this Schmittean account of political legitimacy captures how the US NSS sees legitimacy, what might be its implications for international intellectual property rules? One clear implication is that intellectual property itself becomes ever more instrumentally contingent, drifting further and further away from economic and moral theories of justification. What matters is how intellectual property law serves the security state in military innovation. Intellectual property law comes to operate more like a weapons system in which the rules have to be rewritten to suit new contexts of threat and thought given to innovating new systems of protection.

The TRIPS system is old technology, as it were, in need of refinement and innovation for a world in which, for example, data, cloud computing, machine learning, and robotics are all

\footnotetext{
${ }^{64}$ Elliot V. Converse III, Rearming For The Cold War 1945-1960 (Historical Office, Office of the Secretary of Defence 2012) 292.

65 The distinction between real and absolute enemies is another of Schmitt's well known distinctions. One can reach a settlement with a real enemy but not an absolute enemy. See the essay, Carl Schmitt, Theory of the Partisan. Intermediate Commentary on the Concept of the Political (First published 1963, G.L. Ulmen tr, Telos Press Publishing 2007) 85-95.

${ }^{66}$ Carl Schmitt, The Concept of the Political (First published 1932, Georg. Schwab tr, Expanded Edition, University of Chicago Press 2007) 46.

${ }^{67}$ Carl Schmitt, The Concept of the Political (First published 1932, Georg. Schwab tr, Expanded Edition, University of Chicago Press 2007) 49.
} 
converging at breakneck speed. China's adherence and implementation of TRIPS, part of its condition of accession to the WTO, carries far less weight in a world where innovation has changed so much compared to the 1980s when the rules of TRIPS were formulated. For the US NSS it is all about innovation. Innovation in both the enforcement and the rules of intellectual property become part of the greater enterprise of perpetual military innovation. The shift by the US to bilateral agreements for shaping intellectual property standards occurs because the WTO as a multilateral forum becomes, from a security perspective, mired in issues of development rights and human rights, threatening the US state's capacity to use intellectual property laws as tools of security. And in so threatening the US NSS that multilateral order loses legitimacy. There is little reason to support an order that is seemingly doing little to stop one's enemy from acquiring innovation and developing its own, outstripping, as in the case of $5 \mathrm{G}$ technology, the US in a core area of technology.

Perhaps one might see US behaviour with respect to the WTO, such as the blocking of appointments to the WTO Appellate Body ${ }^{68}$, as a case of Hudec's 'justified disobedience' for the instrumental purpose of achieving reform of the trade order. ${ }^{69}$ One can debate this, but my own view is that the explanation is probably closer to the need to protect the primacy of the political over US security than the desire to deliver reforms of a public good nature to the international trading system.

There is one more reasonably straight forward implication of the Schmittean analysis. There is almost nothing that China will be able to do to satisfy the US on intellectual property. Intellectual property is too bound up with the security mission of the NSS. It is both a weapons system itself (aimed at conditioning the Chinese market, to borrow Hanns Ullrich's terminology) and a system for regulating innovation in weapons systems. The demands from the US for China to do more and more on intellectual property are like a rising tide that never rolls backs its advance. The more successful China is in innovation, the more demands on it there will be.

\section{Conclusion}

In one of the earliest and most comprehensive analyses of TRIPS, Hanns Ullrich describes it as an agreement born of 'fear and aggression'. ${ }^{70}$ Since its operation lawyers have defused, through its integration into the broader corpus of intellectual property principles and public international law, some of its restrictive potential for human rights in key areas such as patents and compulsory licensing. ${ }^{71}$ Missing from the analysis of not just TRIPS but the globalization of intellectual property has been the role of the US NSS. The relationship between intellectual property and US security has always been there. It was there when the US military managed the intellectual property of contractors in US defence procurement, it was there at key moments, as in the case of semiconductor chip technology, when the US lead in innovation was endangered, it was there in the forging of TRIPS and it remains there, now nakedly visible, in the disciplining of China on intellectual property.

\footnotetext{
${ }^{68}$ The US has blocked appointments to the Appellate Body of the WTO Dispute Settlement Body. Its case for doing so is detailed in United States Trade Representative, Report on the Appellate Body of the World Trade Organization, (February 2020) available https://geneva.usmission.gov/wp-content/uploads/sites/290/AB-Report_02.11.20.pdf accessed 20 May 2020.

${ }^{69}$ See Robert E. Hudec, 'Thinking about the New Section 301: Beyond Good and Evil' in Robert E. Hudec, Essays on the Nature of International Trade Law (Cameron May 1999) 153.

${ }^{70}$ Hanns Ullrich, ‘TRIPS: Adequate Protection, Inadequate Trade, Adequate Competition Policy' (1995) 4 Pac. Rim L \& Pol'y J. 153, 207.

${ }^{71}$ The fruits of much of this work are to be found in Matthias Lamping et al, 'Declaration on Patent Protection - Regulatory Sovereignty under TRIPS' (2014) 45 International Review of Intellectual Property \& Competition Law, 679.
} 
As I indicated at the outset of this chapter, my analysis of the political legitimacy of TRIPS is bleak. Searching for new legitimacy foundations for TRIPS is a forlorn enterprise. TRIPS is a multilateral cog in a global intellectual property ratchet, but for the US NSS little more than that. Some 25 years on from TRIPS, innovation is even more globally networked. The days when the US military could run an insider open source operation among its networks of US defence contractors and rightly expect to get the best weapons are well and truly over. Pathbreaking innovation can come from anywhere in global networks. Very different discourses and values about innovation, as the case of the free software movement demonstrates, circulate globally. The US Department of Commerce can put Huawei on its Entity List, but what it cannot do is to stop thousands of Huawei's software engineers from making use of the Linux kernel or other free algorithmic knowledge.

For the US NSS the exclusivity of intellectual property remains a hugely powerful tool with which to counter movements dedicated to free algorithmic knowledge. But, of course, the rules of exclusivity have to be tailored to new technology contexts. TRIPS, as I have argued, is largely yesterday's technology. For US political elites the legitimacy of intellectual property arrangements lies in the service they perform for US military innovation, for it is upon the exclusivity of weapons innovation they have staked the future security of the republic. 


\section{REFERENCES}

Administration Strategy on Mitigating the Theft of U.S. Trade Secrets (February 2013) < https://www.justice.gov/criminal-ccips/file/938321/download> accessed 20 May 2020.

Baldwin, Richard, The Great Convergence: Information Technology and the New Globalization (Belknap Press of Harvard University Press: Cambridge, Mass. 2016).

Barr, William P., 'Keynote Address at the Department of Justice's China Initiative Conference', February 6, 2020, https://www.justice.gov/opa/speech/attorney-general-william-p-barrdelivers-keynote-address-department-justices-china accessed 20 May 2020.

Bresnahan, Timothy F. and Franco Malerba, 'Industrial Dynamics and the Evolution of Firms' and Nations' Competitive Capabilities in the World Computer Industry' in David C. Mowery and Richard R. Nelson (eds), Sources of Industrial Leadership: Studies of Seven Industries (Cambridge University Press: Cambridge 1999) 79.

Carril, Rodrigo and Mark Duggan, 'The Impact of Industry Consolidation on Government Procurement: Evidence from Department of Defense Contracting' (October 2018) NBER Working Paper No. 25160 34-35.

Cheng, Wenting and Peter Drahos, 'How China Built the World's Biggest Patent Office: The Pressure Driving Mechanism' (2018), 49 International Review of Intellectual Property and Competition Law 5.

Cohen, Roger, 'The World Trade Agreement: The Overview; GATT Talks End in Joy and Relief' New York Times (New York, 16 December 1993) Section D, 1.

Congressional Research Service, Enforcing U.S. Trade Laws: Section 301 and China (June 26, 2019) https://fas.org/sgp/crs/row/IF10708.pdf accessed 20 May 2020.

Converse III, Elliot V., Rearming For The Cold War 1945-1960 (Historical Office, Office of the Secretary of Defence, Washington D.C. 2012).

Defense Security Service, Targeting U.S. Technologies: A Trend Analysis of Reporting From Defense Industry 2012 (Defense Security Service 2012).

Drahos, Peter, 'Global Property Rights in Information: The Story of TRIPS at the GATT' (1995) 13 Prometheus 6.

Drahos, Peter, 'BITS and BIPS: Bilateralism in Intellectual Property' (2001) 4 Journal of World Intellectual Property 791.

Drahos, Peter with John Braithwaite, Information Feudalism: Who Owns the Knowledge Economy? (Earthscan:London 2002).

Giffard, Hermione, 'Engines of Desperation: Jet Engines, Production and New Weapons in the Third Reich' (2013) 48 Journal of Contemporary History 821.

Halbert, Deborah, 'Intellectual property theft and national security: Agendas and assumptions' (2016) 32 The Information Society 256.

Hudec, Robert E., 'Thinking about the New Section 301: Beyond Good and Evil' in Robert E. Hudec, Essays on the Nature of International Trade Law (Cameron May 1999) 153

Ilgen, Thomas L., '"Better Living Through Chemistry": The Chemical Industry in the World Economy' (1983) 37 International Organization 647, 653.

Irwin, Douglas A., 'The U.S.-Japan Semiconductor Trade Conflict' in Anne O. Krueger (ed.), The Political Economy of Trade Protection (University of Chicago Press: Chicago 1996) 5. 
Lamping, Matthias et al, 'Declaration on Patent Protection - Regulatory Sovereignty under TRIPS' (2014) 45 International Review of Intellectual Property \& Competition Law, 679.

Lassman, Thomas C., Sources of Weapons Systems Innovation in the Department of Defense: The Role of In-House Research and Development (Center of Military History, United States Army: Washington, D.C. 2008) 2.

Macdonald, Stuart, Technology and the Tyranny of Export Controls: Whisper Who Dares (Macmillan: London 1990).

MacNeil, Robert, 'Between innovation and industrial policy: how Washington succeeds and fails at renewable energy' (2016) 34 Prometheus 173.

Matthews, Duncan, Globalising Intellectual Property Rights: The TRIPs Agreement (Routledge: London and New York 2002).

McCormick, John P., Carl Schmitt's Critique of Liberalism: Against Politics as Technology (Cambridge University Press: Cambridge 1997).

Montroll, Mark, L., 'The Transition Dilemma: Research and Development in the 1990s' in Shannon A. Brown (ed.), Providing the Means of War: Historical Perspectives on Defense Acquisition, 19452000 (United States Army Center of Military History and Industrial College of the Armed Forces: Washington D.C. 2005) 339.

National Counterintelligence and Security Center, Foreign Economic Espionage in Cyberspace (2018), https://www.dni.gov/files/NCSC/documents/news/20180724-economic-espionage-pub.pdf accessed 20 May 2020.

National Research Council, Maximizing U.S. Interests in Science and Technology Relations with Japan (National Academy Press: Washington D.C. 1997)

Odysseos, Louiza and Fabio Petito (eds.), The International Political Thought of Carl Schmitt: Terror, liberal war and the crisis of global order (Routledge: London and New York 2007).

Ryan, Michael, Knowledge Diplomacy: Global Competition and the Politics of Intellectual Property (Brookings Institution: Washington, 1998).

Schmitt, Carl, Legality and Legitimacy (First published 1932, Jeffrey Seitzer, tr and ed, Duke University Press: Durham and London 2004).

Schmitt, Carl, The Concept of the Political (First published 1932, Georg. Schwab tr, Expanded Edition, University of Chicago Press: Chicago 2007).

Schmitt, Carl, Theory of the Partisan. Intermediate Commentary on the Concept of the Political (First published 1963, G.L. Ulmen tr, Telos Press Publishing: New York 2007).

Sell, Susan, K., 'Intellectual property protection and antitrust in the developing world: crisis, coercion, and choice' (1995) 49 International Organization 315.

Ullrich, Hanns, 'TRIPS: Adequate Protection, Inadequate Trade, Adequate Competition Policy' (1995) 4 Pac. Rim L \& Pol'y J. 153.

Ullrich, Hanns, 'The Political Foundations of TRIPS Revisited' in Hanns Ullrich, Reto M. Hilty, Matthias Lamping, Josef Drexl (eds), TRIPS plus 20: From Trade Rules to Market Principles (Springer: Heidelberg 2016) 85.

UNAIDS, Report on the global HIV/AIDS epidemic (June 2000) < http://data.unaids.org/pub/report/2000/2000_gr_en.pdf> accessed 20 May 2020. 
United States Trade Representative, Report on the Appellate Body of the World Trade Organization, (February 2020) available https://geneva.usmission.gov/wp-content/uploads/sites/290/ABReport_02.11.20.pdf accessed 20 May 2020.

Weber, Max, 'Politics as a Vocation' in From Max Weber: Essays in Sociology (first published in 1919, H. H. Gerth and C. Wright Mills, eds and trs, OUP, New York, 1946) 77.

Weiss, Linda, America Inc.?: Innovation and Enterprise in the National Security State (Cornell University Press: Ithaca and London 2014).

Wellerstein, Alex, 'Inside the atomic patent office' (2008) 64 Bulletin of the Atomic Scientist 27.

World Intellectual Property Organization, Patent Cooperation Treaty Review 2017 (WIPO: Geneva 2017).

Yergin, Daniel, Shattered Peace: The Origins of the Cold War and the National Security State (Andre Deutsch: London 1978). 

